\title{
O Encantado: mediações e diálogos da cultura no processo de criação de Attílio Colnago
}

O Encantado: mediaciones y diálogos de cultura em el processo de creación de Attílio Colnago

Aparecido José Cirillo

\footnotetext{
1 Artista e professor na Universidade Federal do Espírito Santo vinculado ao LEENA-UFES (grupo de pesquisa em Processo de Criação); Professor Permanente do Programa de Mestrado em Artes (PPGA/UFES) e do Programa de Mestrado em Comunicação (PPGCS/UFES); Bolsista Produtividade em Pesquisa (PC-FAPES). Desenvolve pesquisas no campo do processo criativo e das relações arte e cidade, com apoio da FAPES e do CNPO. Atualmente é

Coordenador do Programa de Pós-graduação em Artes da UFES.

Lattes: http://lattes.cnpq.br/6252535690546666
} 


\section{Resumo}

A pesquisa desenvolveu-se a partir do uso do corpo através de vivências lúdicas em diálogo com a produção plástica do artista propositor, integrando uma poética pessoal e uma vivência pedagógica em Artes Visuais. Os trabalhos produzidos durante esse processo provocaram uma inquietação que instigou a pesquisa sobre: criação artística, corpo como suporte, experiência estética, exploração de materiais e produção coletiva. Na linha pedagógica a intenção foi criar estratégias que levassem os participantes a explorarem o universo da arte, ampliando seu conhecimento artístico através do Método P.E.R.A, Yoshiura (1982). Na linha artística havia a busca de uma singularidade poética que de maneira muito sutil já trazia a união de técnicas e suportes, configurando-se como uma Hibridação Interformativa, Valente (2008). Desse processo resultaram as séries Desplante e Azuis.

\section{Palavras-chave}

Processo de criação; Criação Coletiva; Artes Visuais;

\section{Resumen}

Este texto trata aspectos compartidos del proceso creativo de Attílio Colnago, especialmente para la muestra "O Encantado" (2014). El enfoque central son las mediaciones entre la mente creativa y la cultura que se materializa como una imagen generadora. Con base en los supuestos de los estudios actuales del proceso creativo, nosotros resaltamos algunos aspectos de la estructura que está cerca del gesto creativo. El texto busca inferir un análisis de un proceso creativo que se constituye como lenguaje de naturaleza dialógica transcultural y (trans)temporal. Inferimos que la interlocución estética de este artista hace de su vivido las matrices culturales y conceptuales que serán impresas en su memoria y en la del público. Sus contenidos amplios son compartidos a través de recursos tecnológicos contemporáneos como Códigos QR. Con esto, buscamos activar la red de relaciones semióticas que nos acerca a las travesuras de la mente creativa y de las formas del espectador recibir y percibir la obra.

\section{Palabras-clave}

Attílio Colnago; Proceso de creación; arte y mediación 


\section{Introdução: a linguagem expressa nos documentos do processo}

Este artigo foi escrito buscando refletir sobre os processos de mediação que se estabelecem em uma ação criativa. Esta visa não apenas gerar uma obra a ser apresentada, mas, sobretudo, a coloca em processo de recepção por parte do público sem acesso aos meandros da mente criadora em ato. Não obstante, o caráter público e comunicativo da arte parece permitir um certo grau de compartilhamento de experiências interpretativas mediadas pelo vivido dos sujeitos (do que produz e do que interage com a obra) interligados pela cultura que os contém.

Partimos do princípio de que a arte é uma manifestação humana, e como tal é, eminentemente, linguagem; ela comunica, pois já se estabelece numa expectativa de mediação com outros sujeitos, constituindo-se como um fenômeno que demarca, significa e comunica (Kristeva,1999). Considerando os documentos do processo de artistas (rascunhos, cadernos de anotações, coleções etc.) como sistemas de memória exteriorizados, pode-se dizer que a interação dos sistemas verbais e visuais desses rascunhos de obra evidencia essa tendência comunicativa no/do processo de criação.

Podemos pensar, portanto, que todas as práticas artísticas que envolvem a obra, ou o processo da obra, são já tipos de linguagem, portanto têm a função de demarcar, significar e comunicar - seja nos processos internos do artista consigo mesmo (diálogos intrapessoais), seja nos processos coletivos envolvendo a percepção da obra exposta (diálogos interpessoais e/ou culturais). Para Cirillo (2004, p.46),

A linguagem expressa nos documentos do processo vai se aproximando de um conteúdo repleto de significações específicas e subjetivas. As imagens grafadas nessas extensões da mente criadora ganham uma nova dimensão sensorial - não completamente uma abstração, mas ganham o caráter de objeto mediado pelo vivido, representação do fenômeno sensorialmente colocado à mente, configurandose como a expressão estendida de uma grafia da memória do sujeito - marcas da experiência vivida, as quais, ao serem apropriadas pelo artista, dele se apropriam.

Assim, os sistemas visuais, como linguagem, se constituem como texto e, como tal, sujeitos aos processos interpretativos de mediação. Em tempos de redes, podem ser ampliados para além dos diálogos do artista consigo mesmo, apontando para um nível de interação sistêmico mais amplo, evidenciado em experimentações dialógicas de caráter interpessoal e cultural que não alteram o sentido do texto, mas the conferem nuances interpretativas ricas que fazem a mediação entre o campo visual e o campo textual. Estabelecem, assim, relações afetivas entre os sujeitos (artista e público), acionando suas memórias e as da obra. Entende-se, pois, por comunicação interpessoal aquela que ocorre entre pessoas frente a frente (DIMBLEY; BURTON, 1990), considerando que toda a interação entre um e outro sujeito é passível de verificação nos documentos do processo dos artistas e nos estudos da recepção da obra exposta. Não obstante, este diálogo prolonga-se ainda com aspectos éticos e estéticos nos diferentes grupos de ação (SALLES, 1998), nos levando a perceber que há níveis de comunicação mais amplos que podem ser acionados nos estudos genéticos (Cirillo, 2004). 
Nesse nível mais amplo, podemos afirmar a existência de uma interação do objeto artístico (e da produção do artista) com o corpo social e com a produção cultural, que vão permitir à representações simbólicas o fomento da apreensão sensível do objeto exposto. Definimos esse nível de interação como diálogos em nível cultural; caracterizam um processo de mediação com a tradição e com tudo aquilo que define e identifica o corpo social como tal: a cultura. Deste modo, o objeto apresentado ao público, exposto aos sentidos, não é exatamente o objeto apreendido (lido).

Assim, tomando reflexões de Paul Valéry (2002), o texto visto (obra exposta) e o texto lido (obra apreendida) são coisas distintas. Portanto, o tipo de mediação com o texto visual pode colocar em movimento sistemas interpretativos distintos e complementares. Esse entendimento é fundamental para entender a metodologia $\mathrm{m}$-learning que desenvolveremos ao longo deste texto.

Para o desenvolvimento de nossa reflexão, tomamos a exposição "O Encantado", do artista capixaba Attílio Colnago e seus documentos de processo como ponto de partida. Parece fato os documentos do processo de Colnago revelarem mediações, citações discorridas para além dos pensamentos do artista consigo ou com o público imediatamente atingido por sua obra. Attílio Colnago revela uma tendência e uma intencionalidade em seu processo criativo que fala com e da cultura visual da humanidade, pelo menos a partir de sua apreensão como linguagem "multisubjetiva" do vivido dessa cultura. Baseados nessa afirmativa, buscamos analisar algumas estratégias de mediação em uma mostra retrospectiva de um artista específico, utilizando equipamentos tecnológicos móveis para redimensionar as possibilidades interativas com a mostra.

\section{Sobre o artista e seus procedimentos}

O uso de dispositivos tecnológicos como mediadores da recepção de uma mostra de arte, o objeto deste artigo, se dá a partir da exposição "O Encantado", realizada em 2014 no Palácio Anchieta, em Vitória, Espírito Santo. Para tal ação investigativa, iniciamos pelo entendimento de quem é o sujeito criador. Quem é Attílio Colnago? Nascido no interior do Espírito Santo, esse artista estudou artes na Universidade Federal do Espírito Santo, onde ingressou em 1973; após se formar, foi professor na instituição até 2017. Sua ênfase é o desenho da figura humana, numa matriz figurativa e clássica, carregada de certo erotismo subliminar, com forte tendência profana (se tomada sua intertextualidade sacra). Teve formação complementar por meio de participação ativa nos festivais de inverno da UFMG, nas cidades de Diamantina e Ouro Preto, em Minas Gerais, quando iniciou o contato com a arte religiosa barroca, influência marcante em seu trabalho artístico. A restauração de arte sacra tornou-se outra atividade regular em sua carreira profissional, dividindo espaço com suas funções de professor e artista. Essa aproximação com o sagrado, corrobora para a consolidação de uma relação entre o sacro e o profano, demonstrando uma intencionalidade poética no artista. Mas, como isto pode ser identificado no processo criativo deste artista? Como seus arquivos pessoais, estudos e projetos evidenciam essa intencionalidade dialógica com a cultura e a materializa no seu projeto poético? 
Põe-se aqui a questão sobre a arte e sua natureza dialógica, e para tal, considerouse: a) a comunicação como a transmissão de informações; b) que toda comunicação humana começa no corpo; e que c) a arte constitui-se como linguagem de natureza dialógica.

A interação dessas questões está marcada nos documentos de processo do artista. Um estudo preciso dos cadernos e arquivos de Colnago parece revelar a dimensão cultural e transtemporal dessas mediações possíveis com o seu processo criativo, desdobrados a partir dos estudos para sua obra. Em seus documentos do processo, predominam combinatórias de signos visuais (poucas anotações verbais) que, embora não se prendendo a leis previamente estabelecidas, estruturam-se como linguagem estabelecida no binômio linguagem-desenho.

Como pode ser percebido na Figura 3, em um esboço inicial para uma pintura que integra a mostra, Colnago chama a imagem cristã do Cristo morto, do corpo deposto que aciona outros campos de sentido. Assim, o processo criador do artista vai se articulando com elementos de si e, em especial, da cultura judaico-cristã. O estudo a caneta é datado do início dos anos de 1990, e a obra (Figura 4) será finalizada em 2007, data correspondente à fotografia do artista deitado (figura 3a). Nessas imagens, Colnago evidencia uma forte presença do universo sacro do Senhor Morto (imagem religiosa comumente presente no Laboratório de Restauração na Universidade Federal do Espírito Santo, do qual foi coordenador por mais de 20 anos, antes de sua aposentadoria em 2018).

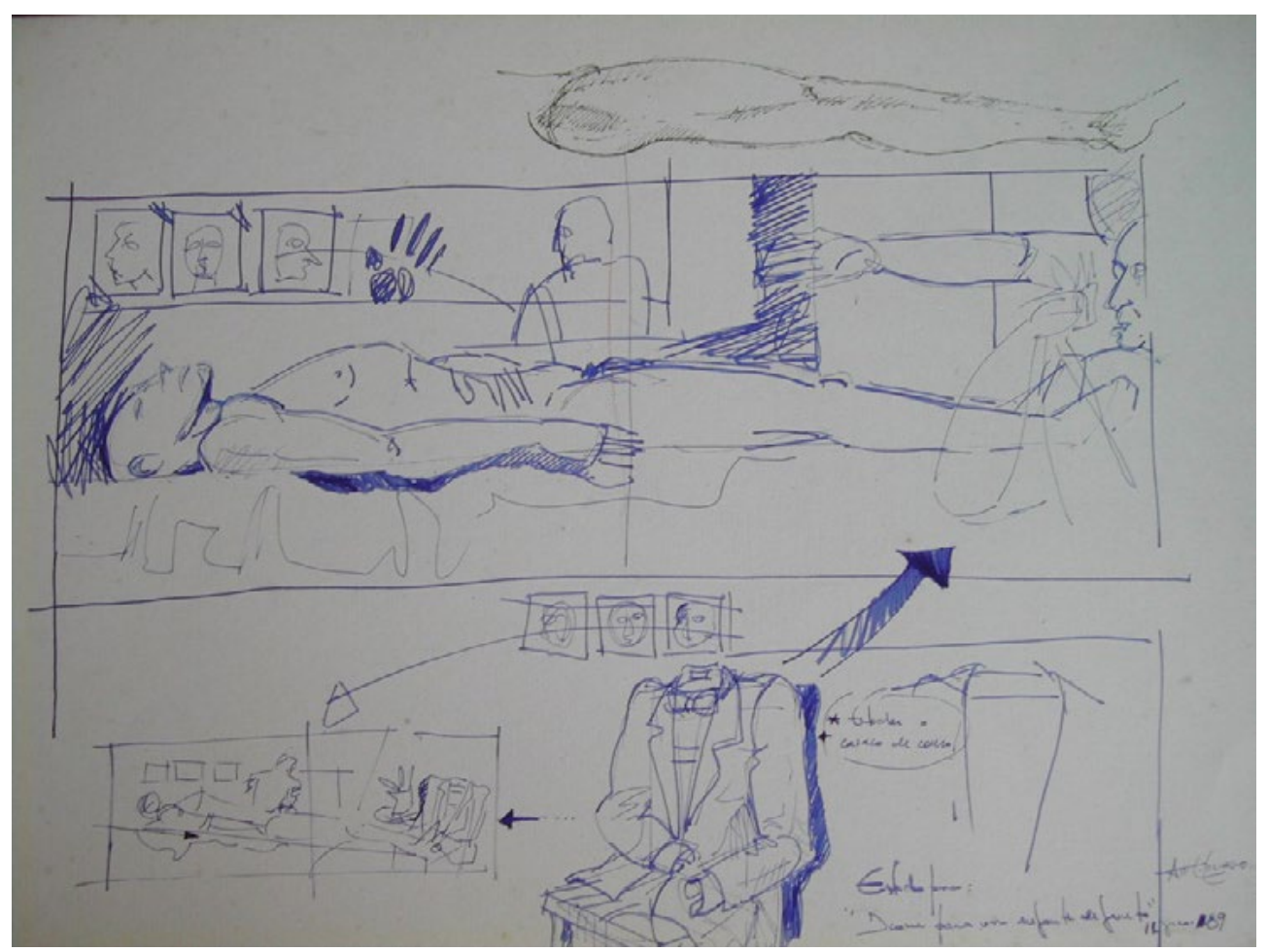

Figura 1 - Etapas de estudos para obra, estudo em caneta sobre papel (acima). Fonte: Banco de Dados do LEENA 

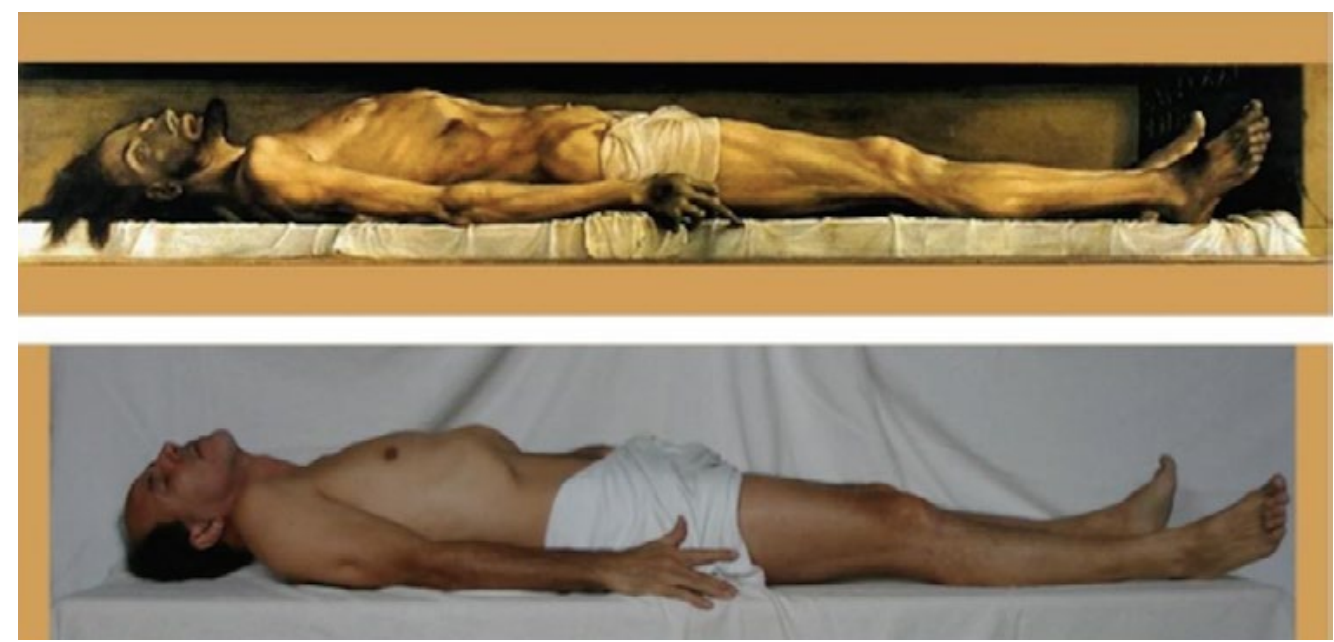

Figura 2 - Etapas de estudos para obra. Fotografia do artista e imagem sacra referencial (Abaixo). Fonte: Banco de Dados do LEENA

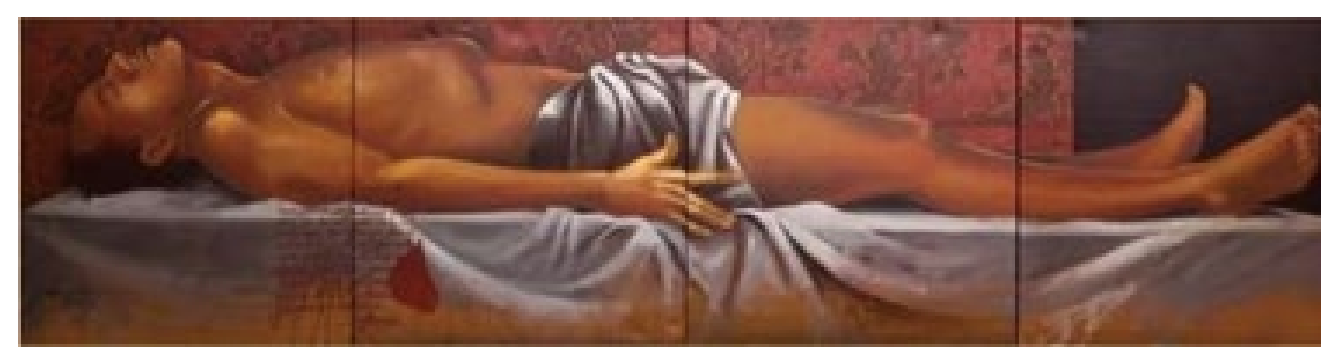

Figura 3 - Senhor Morto ou as Dores que Carrego (2007). Acrílico s/ tela.

Fonte: Banco de Dados do LEENA

De outro lado, a imagem também remete a obras como Lição de Anatomia (1632), de Rembrandt. Ou ainda aos estudos anatômicos de Michelangelo ou de Leonardo Da Vinci. Assim, o desenho a caneta azul e a pintura, entre muitas outras obras e estudos de Colnago, vão colocando à mostra uma tendência poética ao citacionismo (Chiarelli, 2002) - numa interação dialogada com a cultura pictórica que atravessa a história da pintura.

Assim, seus desenhos se põem como parte da materialização e expressão do pensamento criador em ato. Se pode perceber que a linguagem materializada nos desenhos e objetos presentes nos documentos do processo de Colnago (incluindo uma sorte de objetos que, como colecionista, ele organiza em sua casa-ateliê) evidencia o funcionamento da mente criadora num diálogo estabelecido consigo mesmo, com seu público e, principalmente com sua cultura. Isto será potencializado por meio de QR Codes ${ }^{1}$ acrescidos às obras na exposição (objeto deste estudo) e mediados por

1 QR Code: é um código de barras bidimensional para ser usado a partir de telefones celulares equipados com câmera. Esse código é convertido em texto (interativo), um endereço URL, um número de telefone, uma localização georreferenciada, um e-mail, um contato ou um SMS, enfim, esse código remete a informações para além de si, permitindo uma interatividade que amplia a informação sobre o local ou objeto no qual está aplicado. 
uma tecnologia m-learning que permite ampliar os modos de relação do público com a obra e suas camadas dialógicas.

\section{m-learning e estratégias de mediação expandida em tempos móveis}

Vivemos um momento sem igual na humanidade, no qual a informação circula de modo e com uma velocidade jamais vistas anteriormente, acionadas não em palavras, mas em bites. Em especial, por meio de tecnologia de comunicação móvel potencializada com os celulares. Podemos pensar que a apropriação dialógica permitida no aparelho móvel de telefonia parece potencializar a mediação da obra e seus processos e modos de recepção. Amplia também os acessos à linguagem expressa pelo artista, por meio de extensões do vivido materializadas em dispositivos eletrônicos de telas digitais (a realidade virtual propiciada pelos equipamentos de interação digital). Para Cirillo e Ruiz Torres (2015),

[...] $\mathrm{Na}$ verdade, atualmente parecem ser muitos os dispositivos que nos permitem a aproximação com este mundo, coabitante do nosso ambiente, formado por bits de informação no qual a tela, do nosso computador ou do nosso celular, torna-se pontos de acesso primordial do chamado homo ecranis (Lipovetsky e Serroy, 2009). No campo da arte, estes meios de mediação estética são cada vez mais presentes, não apenas como um dos suportes da arte com novas mídias [...], mas também como um meio de difusão, de acesso e interação com a obra de arte, para além da sua fisicalidade nos espaços expositivos ${ }^{2}$

Para a mostra "O Encantado", estabelecemos um processo curatorial para a chamada "Sala de Memória", na qual os documentos do processo criativo de Colnago eram compartilhados tendo expostos aspectos de sua intimidade criadora com o público no espaço expositivo. E, com esse olhar, nos aproximamos do processo criativo do artista, de sua preparação para a montagem dessa exposição, e dos desdobramentos interativos provocados por nós, a partir da metodologia de m-learning (aprendizagem por meio de tecnologia móvel digital).

A sala de memória (Figura 4) era composta de um conjunto de fac-símiles dos cadernos de rascunhos do artista (manipuláveis pelo público); alguns originais emoldurados de seus documentos; três vídeos interativos que permitiam ao público "navegar" pelos estudos do artista; e uma instalação audiovisual que compartilhava a intimidade do ateliê do artista.

Além disto, ao longo das grandes salas da exposição, cada obra tinha um QR Code que carregava informações complementares sobre a produção daquela obra específica. Utilizamos tecnologias em equipamentos móveis de comunicação como

2 CIRILLO, A. J.; RUIZ TORRES, DAVID. Mediações digitais na obra do artista: diálogo e interação no (ciber)espaço expositivo. In: 14o Encontro Internacional de Arte e Tecnologia: \#14.ART: Arte e desenvolvimento humano, 2015, Aveiro (Portugal). 14o Encontro Internacional de Arte e Tecnologia: \#14.ART: Arte e desenvolvimento humano. Aveiro: UA Editora, 2015. v. 1. p. 79-82. 
facilitadores dessa mediação cultural com imagens geradoras do e no processo criativo desse artista (Figura 5), possibilitando o acesso a códigos remotos que ampliam as relações de percepção do texto visto (a obra exposta).

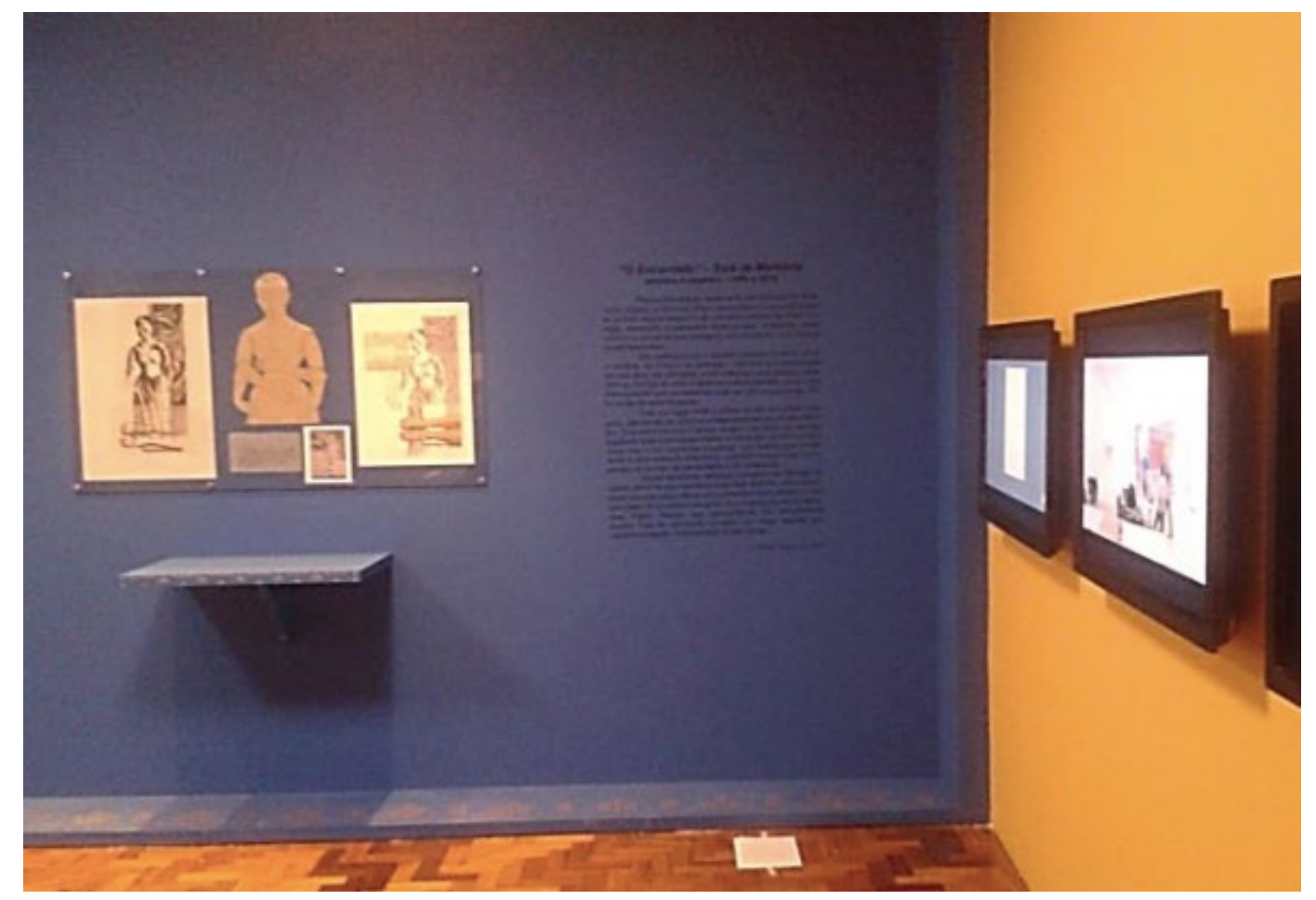

Figura 4 - Vista parcial da "Sala de Memória" (Curadoria de José Cirillo e David R. Torres). Exposição "O Encantado", de Attílio Colnago (2014). Fotografia do David Ruiz Torres. Fonte: Banco de Dados do LEENA

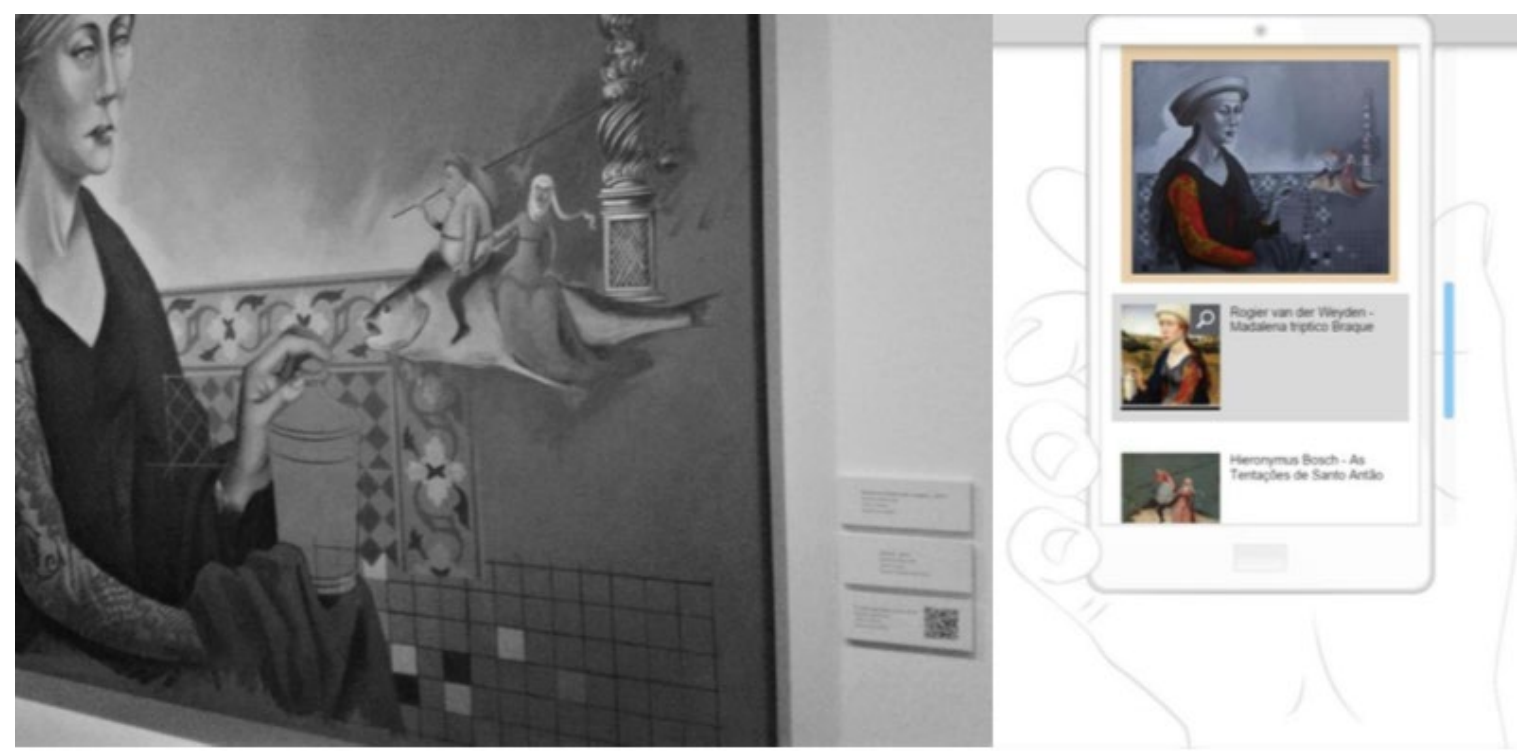

Figura 5 - Vista parcial da mostra com o QR Code ao lado das obras (esquerda) e visualização no celular da leitura do QR Code (direita). Exposição "O Encantado", de Attílio Colnago (2014). Fotografia do David Ruiz Torres. Fonte: Banco de Dados do LEENA 
Esse conjunto de códigos remotos complementa os processos dialógicos com a obra, ampliando o espaço expositivo para o espaço virtual das vivências do público; por sua vez, este se apropria de outros modos de recepção de cada objeto e de suas interações com a cultura e com o campo das artes mundiais. São diálogos multidimensionais. Assim, essa interação multidimensional pode ser acionada no espaço expositivo por meio das tecnologias digitais, ampliando os modos de recepção e fruição da obra e de seu processo. Esse universo gerador da obra vai ser levado como imagem por meio da mediação digital e acessada por um QR Code.

A cultura com a qual Colnago interage vai se manifestar em diferentes linguagens e meios no processo deste artista, tornando-o "partícipe" da sociedade do passado, mas constantemente mediado por seu tempo - um tempo devedor, cada vez mais, do meio digital. Sua ação processual, no entanto, não considera apenas como ele vê ou se apropria dessa tradição da pintura. Da mesma maneira que o artista constitui seu trabalho abraçando e ressignificando diferentes expressões artísticas históricas, tanto formal, quanto material ou tecnicamente, ele pensa que a obra resultante deste processo deve dialogar com a capacidade do público de estabelecer as mediações temporais e referenciais. A proposta curatorial da "Sala de Memória" com mediação em m-learning visa ampliar essas interações e acionamentos no público.

A forma como sua obra é compartilhada ou transmitida deve consideraro presente do seu público e a potencialidade para comunicar a linguajem estudada e realizada pelo artista. Este aspecto pode ser dialogado em diferentes cenários corpóreos ou incorpóreos através dos diferentes processos de mediação, potencializando a questão comunicativa da obra do artista. Pensando nisto, e centrados na metodologia m-learning como estratégia de mediação em espaços expositivos, planeamos os QR Codes como proposição mediativa nesses tempos de redes virtuais.

[...] esta civilización de lo virtual que vivimos también se caracteriza por la rápida sucesión de cambios tecnológicos y de nuevas adaptaciones informáticas que denotan un ritmo frenético en cada una de las facetas por las que se encuentra afectado. En este caso la educación en red o e-learning también ha comenzado a sufrir ciertos cambios, especialmente con la aparición de los dispositivos portátiles que ha llevado a multiplicar los contextos de aprendizaje estableciendo un diálogo más estrecho entre las instituciones educativas y otros contextos de aprendizaje informal a través de lo que ha comenzado a llamarse como el m-learning. ${ }^{3}$

Ruiz Torres estuda modos pelos quais o mundo digital tem afetado processos de interação entre o público e espaços expositivos na Espanha e no Brasil. Ruiz Torres foi curador adjunto da "Sala de Memória" nesta exposição "O Encantado", o que permitiu ampliar os procedimentos mediativos utilizando equipamentos digitais, colocando em ação o processo do m-learning e sua relevância nos processos de mediação em espaços de mostras em Vitória, em específico no espaço cultural Palácio Anchieta -

${ }^{3}$ RUIZ TORRES, DAVID. Arte y mediación a partir de las tecnologías digitales móviles: prácticas de m-learning en espacios expositivos. 2018. (Apresentação de Trabalho/Comunicação. João Pessoa: 2o. Congresso Intersaberes em Arte, Museus e Inclusão; Inst. promotora/financiadora: Universidade Federal da Paraíba. 
sede do governo estadual e locus da mostra em estudo.

\section{A circulação de signos intersubjetivos: mediações possíveis}

Se as investigações iniciais do processo de Colnago para a mostra "O Encantado" nos levam ao contexto psicossocial da comunicação, sua análise nos conduz à verificação da relação das imagens de fenômenos do mundo sensível com a mente criadora que permite ao "leitor" compartilhar alguns dos esquemas mentais do ato de criação; e, não obstante, nos leva ao compartilhamento das relações do homem (artista ou público) com os fenômenos sensíveis. Esses fenômenos aparecem à mente do público e causam-lhe um efeito que gera movimento: mediação, ou no caso de Colnago, seria melhor dizer "mediações" - tamanha a rede de significações que se estabelecem a partir de sua obra.

Como podemos observar na Figura 5, sua obra é repleta de elementos apropriados tanto da história da arte, quanto de sua coleção de objetos em seu ateliê, ou ainda de imagens do cotidiano ordinário, como as peras e maçãs. Nessa imagem, a referência ao mundo imaginário insólito de Bosch, por exemplo, é evidente na parte central direita da imagem. Porém, esse uso de imagens ordinárias ou apropriadas da história da arte não é ocasional, ele é simbólico. Nas obras de Colnago, as maçãs falam da perfeição e das paixões; as peras da imortalidade; etc.; assim, suas formas remetem ao simbólico e dizem do que os olhos aparentemente não leem, mas a percepção do espectador capta e realiza como experiência do sensível, articulada com uma memória cultural ocidental que constitui a humanidade.

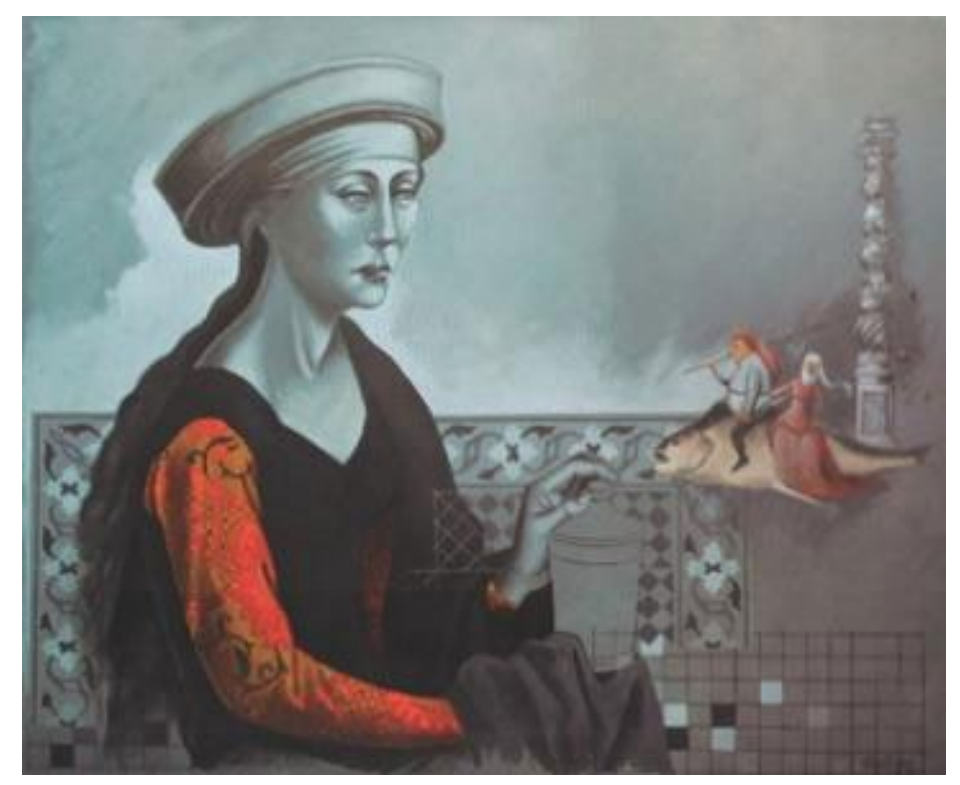

Figura 6: Van der Weyden e Bosch são tomados como referência nesta obra de Colnago. Fonte: acervo do artista

Nesse sentido, pode-se pensar que Colnago intervém no modo de percepção dos objetos colocados aos sentidos: em seu processo criativo, coabitam o tradicional e o estranho, o natural e o imaginário, o autoral e o citacional, o atual e o virtual 
(não no sentido do ciberespaço, mas, naquele primeiro presente na imaginação, nos sonhos e nas fantasias que nos assolam e consolam os desejos). Em seu projeto poético, coabitam as dualidades e o hibridismo. Suas formas resultam de convenções com maior ou menor fixidez e falibilidade, dependendo de um conjunto de variáveis psicológicas, sociais e culturais que ele toma ao longo do processo de construção de cada obra.

A relação de recepção se dá, então, a partir da circulação desses signos intersubjetivos, os quais só podem combinar com outros signos de modo mais ou menos limitado ou reconhecível, estabelecendo a comunicação entre o artista e seu público. Estabelece-se como um ato inerente à interação humana que resulta em uma obra que forma um conjunto polissêmico que conduz à diversidade infinita de compreensões desse fenômeno que é a vida cotidiana, tomada pelo prisma dos interiores. Attílio fala da dialética dos interiores (de cada humano e dos espaços).

Considerando que existe um processo de transmissão e armazenamento de informações compartilhadas pelo artista e pelos sujeitos que se põem diante de sua obra, podemos inferir que Attílio também aborda esse ponto em comum. E isso se dá em níveis diversos de mediação: aquele da cultura local, bem como no chamado da cultura mundial, quando evoca em suas obras, ecos da história simbólica e imagética mundial.

Definitivamente, não é só um diálogo unilateral e intrasubjetivo. Colnago parece construir uma congruência entre o emissor (o artista e ou os signos presentes em sua obra) e a interpretação do receptor (público), bem como parece haver uma intencionalidade em seu projeto poético, tentativa consciente de influenciar o receptor por meio de mensagens subliminares, dispostas para além das formas exibidas - não exterior a elas.

Em Colnago, parece haver outro universo que se constitui em paralelo à sua obra apresentada - o qual, por meio das tecnologias contemporâneas utilizadas nessa mostra do artista (por opção do projeto curatorial), nos parece ter sido acessado. Acreditamos que alguns desses labirintos por onde sua mente criadora se enveredou, ao produzir uma obra ou o conjunto delas, foram apontados na escolha do m-learning como estratégia para dar visibilidade rizomática a estes percursos criativos do artista.

Colnago compartilhou esses seus devaneios pelo tempo da pintura como linguagem. Em "O Encantado", o artista permitiu sua privacidade criativa ser invadida por milhares de olhares. Para tal, o projeto curatorial previu mediações do público a partir de aplicativos em smartphones que permitiram ao público, como um voyeur, sentir sua "libido platônica", uma paixão criativa com o artista em seus devaneios poéticos. Esse compartilhamento digital das interações possíveis da mente criadora reflete um novo modo de pensar o compartilhamento dessas relações no campo da recepção da obra.

Retomando Ruiz Torres e Cirillo (2015), a atualidade enfrenta um momento de vivência digital sem precedentes, em especial por meio das tecnologias digitais móveis, como os smartphones, tornando cada vez mais significativos os processos de m-learning, incorporados por diversos espaços expositivos como galerias e 
museus, pautando-se num processo de aprendizagem informal que complemente as informações da obra exposta no processo de mediação com essas. Assim,

[...] a estratégia do uso de QR Codes e a tecnologia dos smartphones ou outros tipos de aparelhos de mídia portáteis, foi utilizada para promover e testar outros modos de leitura e mediação. Nesse ato de mediação e "leitura" do público, podemos lembrar a Giselle Beiguelman que tem se referido aos QR Codes como "a primeira forma de escrita desenvolvida pra leitores nômades" (2013, p. 149), referindo-se a tendência crescente do uso de dispositivos portáteis que em nossa experiência serviram como suporte para a mediação. O público, na mostra de Colnago, é provocado a se colocar como errante nesses espaços para além do espaço físico da obra. ${ }^{4}$

Para Ruiz Torres e Cirillo, o uso dessa estratégia metodológica complementar ao processo receptivo da obra, propicia outros modos de percepção. No caso de Colnago, mapeamos seu processo criativo e destacamos os principais elementos ou imagens geradoras, para com eles acionar um plano de relações digital que pudesse complementar os procedimentos receptivos da obra, ampliando suas relações de recepção.

Para essa mediação complementar digital, criamos os QR Codes que conduzem o público para uma página no Wix ${ }^{5}$ que vai fornecer informações adicionais (Figura 5) sobre os elementos da obra e as referências citacionistas no processo de Colnago.

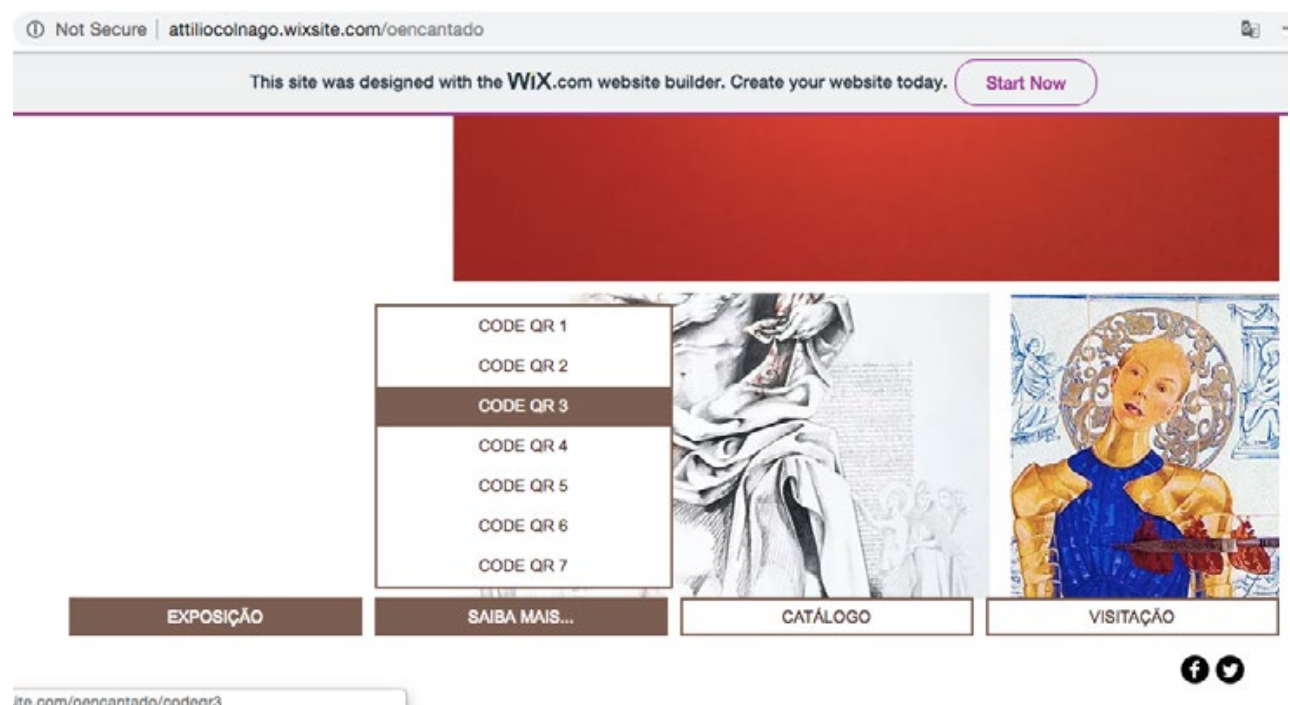

Figura 7- Páginas do WIX para a mostra O Encantado.

Disponível em http://attiliocolnago.wixsite.com/oencantado/Fonte:

Banco de Dados do LEENA.

${ }^{4}$ RUIZ TORRES, D.; CIRILLO, J. Tecnologias da Informação e Mediação nos Espaços Expositivos a partir da Exposição O Encantado, de Attilio Colnago. In: 24o Encontro Nacional da ANPAP, 2015, Santa Maria, RS. Anais do XXIV Encontro da Associação Nacional dos Pesquisadores em Artes Plásticas; Compartilhamentos na arte: redes e conexões. Santa Maria: ANPAP, Universidade Federal de Santa Maria, 2015. v. 1. p. 2799.

${ }^{5}$ WIX é uma plataforma digital de criação e edição de sites, independente de conhecimento prévio do usuário da linguagem HTML. 
Nas figuras 7 e 8, temos a página de entrada e uma das demais páginas de um sítio eletrônico para o qual o visitante da mostra era levado a partir de um QR Code disponível ao lado das obras (Figura 2). Assim, imediatamente foram compartilhadas algumas das fontes ou imagens geradoras do artista em seu processo criativo. Nessa página Wix, o leitor/público/visitante tem acesso a páginas navegáveis que podem levá-lo a dimensões diferentes da mostra (EXPOSIÇÃO); ao CATÁLOGO; a estratégias da VISITAÇÃO; ou a outras informações (SAIBA MAIS - nestas, o acesso aos diferentes QR Code que trazem informações complementares (Figura 7).

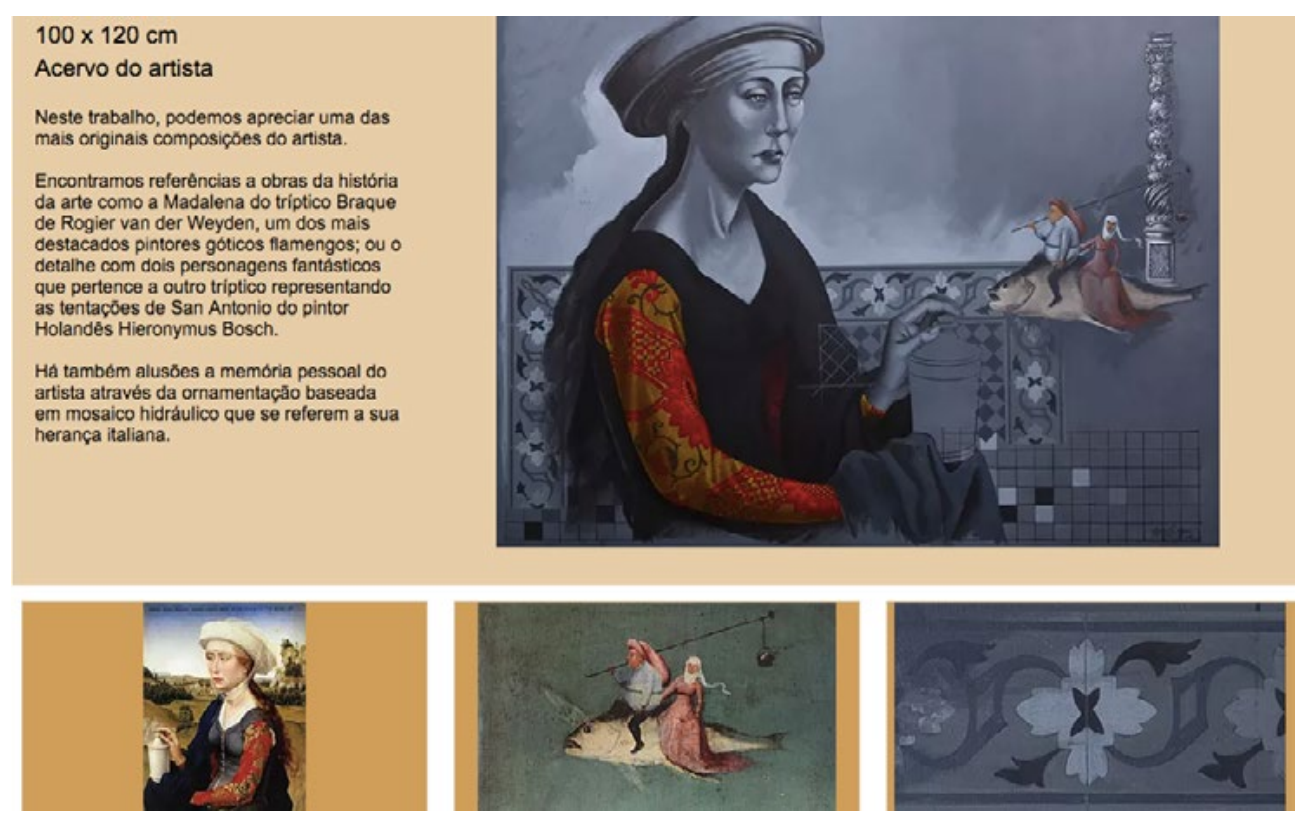

Figura 8- Páginas complementar do Wix para a mostra "O Encantado", acessível com o clique em CODE QR Disponível em http://attiliocolnago.wixsite.com/oencantado/ .

Fonte: Banco de Dados do LEENA

O texto em cada página Wix vai conduzindo e acrescentando informações ao processo interativo do público com a obra. Assim, podemos dizer que as possibilidades oferecidas pelas redes digitais representam uma sobrevivência da memória comunicativa do artista, além de um desdobramento da sua obra em nosso presente; supõem, neste estado de sobrevivência, uma presença quase imortal e eterna que transcende a experiência atual do seu trabalho em um tempo definido e fechado, e consegue uma durabilidade que ultrapassa o tempo do artista. Além de nosso tempo presente, como um legado para as gerações futuras através do médio digital.

\section{Considerações Finais}

A presença digital como estratégia de intervenção e apreensão da mostra de Attílio Colnago pode estabelecer, ou ampliar, a rede de informações contida no 
processo de cada obra. Em "O Encantado", o meio digital se colocou como uma opção curatorial adicional de interação, tendo como proposição a possibilidade para ampliar as relações de mediação interativa. A proposta estava atendendo a uma informação que é compartilhada; neste caso, a obra exposta ao público vai se desfiando conforme as eleições do emissor e do receptor. Esses interatuam por meio de equipamentos tecnológicos digitais, ampliando a sua participação na memória compartilhada, dando outra entidade existencial ao seu trabalho. Quando apresentadas e reconhecidas, essas mediações da mente criadora vão tornando presente o trabalho criativo do artista, revelando seus diálogos e do público com a memória cultural do ocidente.

No entanto, não é apenas uma relação estabelecida entre o artista, sua obra e o público: torna-se necessário atender à comunicação entre o mesmo público, como parte de sua participação. Isto porque a experiência vivida frente à obra de arte é desfrutada em muitos sentidos: desfruta-se no tempo da experiência estética ou no momento posterior a essa experiência, como lembrança no tempo em que reaparece. A este respeito, os recursos do meio digital e dos procedimentos m-learning atuam como uma presença etérea fora do espaço de exposição, do espaço sagrado do cubo branco, no qual a obra da arte assume sua materialidade.

No ciberespaço, a obra é um fenômeno como os demais, desprovidos de hierarquia que a isole em uma torre emoldurada pelo sistema convencional das artes. No ciberespaço, a obra assume sua natureza sensível, pública e coletiva.

Assim, a proposição dialogada pressuposta em "O Encantado" revela em si a existência de uma intenção. Revela a intencionalidade de um artista que busca afetar a mente do receptor (ele mesmo e o público), estabelecendo níveis de interação que circunscrevem os diferentes sujeitos, os quais são intencionalmente ampliados, via ação curatorial, com o uso de recursos de mediação digital.

O diálogo cultural que congrega as estruturas do organismo social e suas tradições, talvez seja uma das mais expressivas formas de comunicação expressa nas obras de Attílio Colnago - potencializadas nesta mostra por meio de interações digitais dos QR Codes. Parece que se expressa em sua obra a conjunção de seu imaginário que dialoga com a cultura de seu tempo. Dialoga com o passado das artes. Dialoga com a tradição da manufatura, dos ofícios e mesmo das guildas medievais. Lança mão do que seja necessário para construir uma obra que revela a maturidade poética deste artista. Lança mão, sobretudo, de sua capacidade de ativar a memória de tudo o que lhe constitui, e habilmente daquilo que tangencia o compartilhamento com o outro.

Em alguns momentos, temos certeza de que ele toma para si uma tendência citacionista: se coloca, como aponta Tadeu Chiarelli (2002, p. 100-110), em busca de trabalhar com "imagens de segunda geração" - aquelas que são apropriadas de algum tempo cultural, são analisadas e transformadas, deixando marcas processuais tanto nos documentos da obra quanto nos processos interativos da recepção por parte do público.

Essas marcas parecem ser capazes de nos levar a contextos mais amplos, embora não possamos entrar na mente do artista. Os processos do m-learning ampliam nossa 
capacidade de simular correlações da mente criadora. Assim, podemos tomar como instrumento dessa ativação os processos tecnológicos da contemporaneidade, os quais permitem que toda uma rede de relações possa ser reconectada, operada como chaves que nos aproximam das artimanhas da criação em ato. Olhar o ato do criador é como olhar o céu e suas nuvens, se não cerrarmos os olhos, se não buscarmos nossas vontades e desejos, as nuvens brancas passam com o vento. Serão apenas nuvens brancas.

\section{Referências}

CAMPOS, Haroldo de. Da transcriação poética e semiótica da operação tradutora. Belo Horizonte: FALE/UFMG, 2011.

CIRILLO, Aparecido José. Imagem-lembrança: comunicação e memória no processo de criação, 2004. 161p. Tese (doutorado em Comunicação e Semiótica). Pontifícia Universidade Católica de São Paulo. São Paulo, 2004.

CHIARELLI, Tadeu. Arte internacional brasileira. São Paulo: Lemos, 2002.

KRISTEVA, Julia. História da linguagem. Tradução de Maria Margarida Barahona. Lisboa: Edições 70, 1999.

RUIZ TORRES, D.; CIRILLO, J. Tecnologias da Informação e Mediação nos Espaços Expositivos a partir da Exposição O Encantado, de Attilio Colnago. In: 24o Encontro Nacional da ANPAP, 2015, Santa Maria, RS. Anais do XXIV Encontro da Associação Nacional dos Pesquisadores em Artes Plásticas; Compartilhamentos na arte: redes e conexões. Santa Maria: ANPAP, Universidade Federal de Santa Maria, 2015. v. 1. pp. 2792 -2806.

VALERY, Paul. As duas virtudes de um livro. Trad. de Dorothée de Buchard. In: Suplemento Literário de Minas Gerais, n.88, outubro de 2002.

Recebido em 30 de maio de 2020.

Aprovado em 20 de julho de 2020. 